\title{
Speech, Language and Hearing Sciences in Workers' Health Reference Centres in Brazil
}

\author{
Aline Cristina Gusmão(1) \\ Tatiane Costa Meira ${ }^{(1)}$ \\ Franciana Cristina Cavalcante Nunes dos Santos ${ }^{(1)}$ \\ Silvia Ferrite ${ }^{(1,2)}$
}

(1) Universidade Federal da Bahia, Instituto de Saúde Coletiva, Salvador, Bahia, Brasil.

(2) Universidade Federal da Bahia, Departamento de Fonoaudiologia Salvador, Bahia, Brasil.

Study (partially) presented and awarded at the 23rd Brazilian Congress of Speech Language and Hearing Sciences in 2015. Research support sources: Scientific Initiation Grant - Permanecer Programme/ UFBA; Project 7026. Plan number: 14078/2014 (Gusmão, AC).

This study was partially financedby the Coordenação de Aperfeiçoamento de Pessoal de Nível Superior - Brasil (CAPES) - Finance Code 001

Conflict of interests: Nonexistent

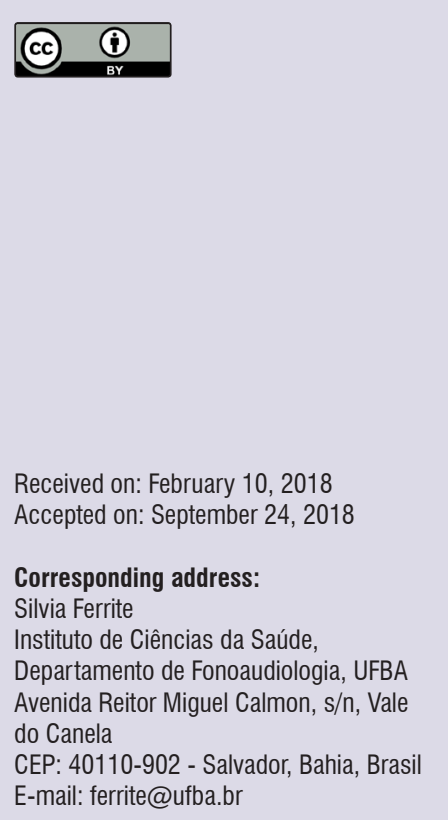

\section{ABSTRACT}

Purpose: to investigate the presence of Speech-Language and Hearing (SLH) professionals in the teams of Workers' Health Reference Centres (Centros de Referência em Saúde do Trabalhador - CEREST) in Brazil, their distribution and features related to inclusion and activities.

Methods: a descriptive, epidemiological study, in which all the CERESTs in the country were units of observation. Primary data were collected by applying a questionnaire to the CEREST Coordinator or one of their designated representatives.

Results: 158 of the 199 eligible CERESTs participated in the research. In 2014, 48.1\% of these CEREST had an SLH professional on their team, with the highest number in the Southeast and the lowest in the North Region. When present, statutory contracts were the most common form of employment. Approximately $75 \%$ of the CEREST with a SLH professional in the team reported surveillance activities in general, as well as actions specific to noise-induced hearing loss and work-related voice disorders. However, in $7.9 \%$ of these units, the SLH professionals were exclusively dedicated to clinical care.

Conclusion: this study describes and examines the incipient inclusion of SLH professionals in CEREST, providing evidence that indicates regional inequalities and reveals that, despite generally working in health surveillance activities, there remain units where the SLH professionals are only dedicated to specialized care.

Keywords: Speech, Language and Hearing Sciences; Occupational Health; Public Health Surveillance 


\section{INTRODUCTION}

According to the Ministry of Health (2001), Workers Health (WH) may be understood as an area of Public Health whose object is the study of and intervention in the relationship between working conditions and the population's health. WH activities aim to promote health, care and welfare, as well as surveillance measures related to occupational exposure and workrelated injuries. Of these injuries, two may compromise the worker's communication abilities: Noise-Induced Hearing Loss (NIHL) and Work-Related Voice Disorders (WRVD).

NIHL arises from continued exposure to high sound pressure levels and is manifest in the gradual and irreversible reduction of auditory acuity ${ }^{1-3}$, which may compromise the worker's quality of life and generate costs to the individual themselves, their family and society ${ }^{4,5}$. NIHL, however, is preventable, through the adoption of collective or individual measures ${ }^{6}$. For its part, WRVD may be understood as any form of vocal deviation directly related to voice use during one's professional activities which reduces, compromises or impedes the worker's operations and/or communications and which may cause emotional harm in their professional or socioeconomic activities ${ }^{7-9}$.

According to Law 6,965, 9 December 1981, a Speech, Language and Hearing (SLH) professional is someone whose training and mission of care refers to individual health in relation to human communication in its various aspects, working for the promotion of health and the prevention, diagnosis and rehabilitation of disorders, such as those related to voice and hearing. Resolution 428 (2013) of the Federal Council of Speech, Language and Hearing Sciences sets out that, in the sphere of WH surveillance activities, it falls to the SLH professional: to conduct situational environment diagnosis, to ascertain the Speech, Language and Hearing epidemiological injury profile, to act to improve environmental conditions for the prevention of risks, to recommend individual protection equipment, and to monitor, devise and manage activities aimed at the general health and wellbeing of workers. It is therefore understood that an SLH professional involved in WH must be guided by comprehensive care, not restricting themselves to their specific welfare activities or to their area of speciality.

In 2002, Decree 1679 established the National Network for Comprehensive Worker Healthcare (Rede Nacional de Atenção Integral à Saúde do TrabalhadorRenast) in Brazil. This is a network for information and health practices whose aim is to expand $\mathrm{WH}$ activities across the Unified Health System (Sistema Único de Saúde - SUS) and coordinate intra- and intersectoral surveillance and health promotion activities to promote comprehensive care for all workers across the country ${ }^{10}$. According to Decree $2437 / 2005$, the provision of a technical support for WH activities in SUS is the function of Worker Health Referral Centres (Centros de Referência em Saúde do Trabalhador - CEREST).

According to the above-mentioned decree and the Manual for the Management and Administration of Renast (2006), the minimum technical team for a state CEREST includes at least five mid-level and ten top-level professionals, while for the regional CEREST, this is at least four mid-level and six top-level professionals. The SLH professional is included in the list of professionals who may be allocated to the team, although this is not compulsory, as is also the case with orthodontists, engineers, psychologists, social workers, physiotherapists and others. However, the 2009 Decree 2437/2005 was revoked and the proposed minimum composition of the CEREST team is now on the agenda for discussion regarding changes to Renast. Although the SLH professional may form part of the team, descriptive studies about SLH professionals at CEREST were not found. The aim of this study, therefore, is to investigate the presence of SLH professionals in CEREST teams in Brazil, including their distribution and features related to inclusion and activities.

\section{METHODS}

The study was approved by the Research in Ethics Committee of the Institute of Collective Health at the Federal University of Bahia (Protocol 074-14; Decision 648.023) and all the respondents agreed to participate by signing a Free and Informed Consent Form.

This is a descriptive, epidemiological and ecological study, in which all the CERESTs in the country were the units of observation. In order to define the set of CERESTs to be investigated, we considered eligible all those units registered by Renast in 2014 as having been fully functional since 2013 . The exclusion criteria were, therefore, units still in the installation phase in 2013 or whose accreditation had been suspended.

Data collection took place between June and December 2014. A structured questionnaire in electronic format was sent to the institutional email address of regional and state CEREST. The e-mail, with a link to the electronic form, was sent to the coordinators, who were able to designate another team member to 
complete it, if desired. Through the questionnaire, we obtained information about the presence, number, type of contract, length of operation and type of activities undertaken by SLH professionals at the CEREST (see Appendix). We made two further attempts to contact the CEREST that did not respond, the first via e-mail, using an alternative electronic address, where possible, and the second via telephone, applying the same questions in order to obtain data.To guarantee privacy during the telephone application, a convenient time was booked, according to respondent availability.

Study variables were: number of SLH professionals since the commencement of CEREST activities; presence of an active SLH professional on the team; having had an SLH professional on the team in the past; the SLH professional's employment contract (categorized as statutory civil servant, temporary/outsourced contract, voluntary and other); type of activities undertaken by the SLH professional, operationalized into three categories: a) specialized clinical care (in specific areas, such as voice or hearing); b) surveillance in a specific area (health surveillance activities related to NIHL and/or WRVD; c) health surveillance (health surveillance activities in general). The descriptors were calendar year, federal state and geographical region.

The database generated from responses to the electronic form was transferred to an Exce ${ }^{\circledR}$ spreadsheet and complemented with a record of responses obtained by telephone. Our analysis estimated frequency of agreement with variable categories. These analyses were conducted using the statistical programme SAS 9.4 and Microsoft Excel ${ }^{\circledast}$. The geo-referencing programme QGIS 2.6 was used to construct the map.

\section{RESULTS}

Of the 210 state and regional CEREST registered with Renast in 2014, 199 were fully functional in 2013.
Of the 11 CERESTs excluded, nine were in the installation phase and two had had their accreditation suspended. Out of the 199 CERESTs, 158 participated (79.4\%); this constituted the study population. Of the 27 federal states, only Acre and Amapá did not have participating CERESTs.

Of the 158 CERESTs, the majority (87.3\%) responded via electronic form. The CERESTs coordinators were the most common respondents $(51.3 \%)$, followed by an SLH professional (24.0\%) and, less commonly, other members of the team, such as a nurse, physiotherapist, doctor and others. In three CERESTs, the coordinators were SLH professionals.

In $2014,48.1 \%$ of the participating CERESTs had an active SLH professional(s); $13.9 \%$ had had one in the previous period, but not in 2014 , and $38.0 \%$ had never had this type of professional on their team.In 2014, the number of units with an SLH professional on their team was approximately four times higher than the estimated number in 2002, based on data referred to by the respondents (Figure 1).

Figure 2 presents the spatial distribution of the CERESTs around the country according to presence or absence of an SLH professional on the team. The Southeast region had the greatest proportion of CERESTs with an SLH professional, in contrast to the low representation in the North region (Table 1). If we look at the federal states around the country, the highlights are Rio Grande do Sul and São Paulo, with $72.7 \%$ and $60.0 \%$ of their CERESTs having at least one $\mathrm{SLH}$ professional, respectively. Although the states of Maranhão, Alagoas and Roraima had fewer CERESTs, in 2014, all of these had an SLH professional. However, there was no such professional in the CEREST teams in Rondônia, Tocantins, Paraíba, Mato Grosso do Sul and Paraná. In Paraná specifically, none of the eight CERESTs had an SLH professional. In Bahia, one of the 13 CERESTs had an SLH professional. 


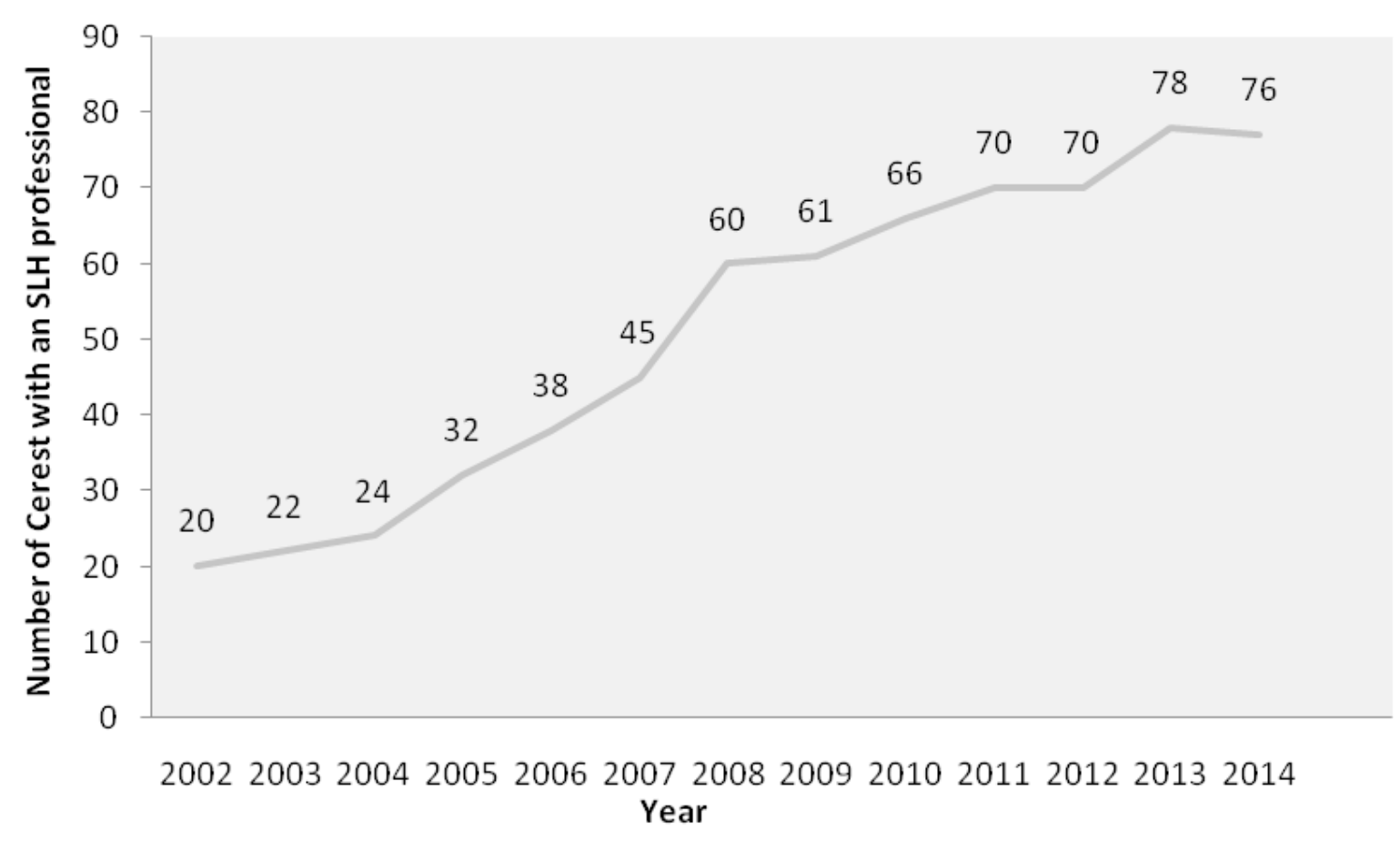

Figure 1. Distribution of Worker Health Reference Centres (CEREST) with an SLH profession, by calendar year in Brazil (N=158), 2002-2014

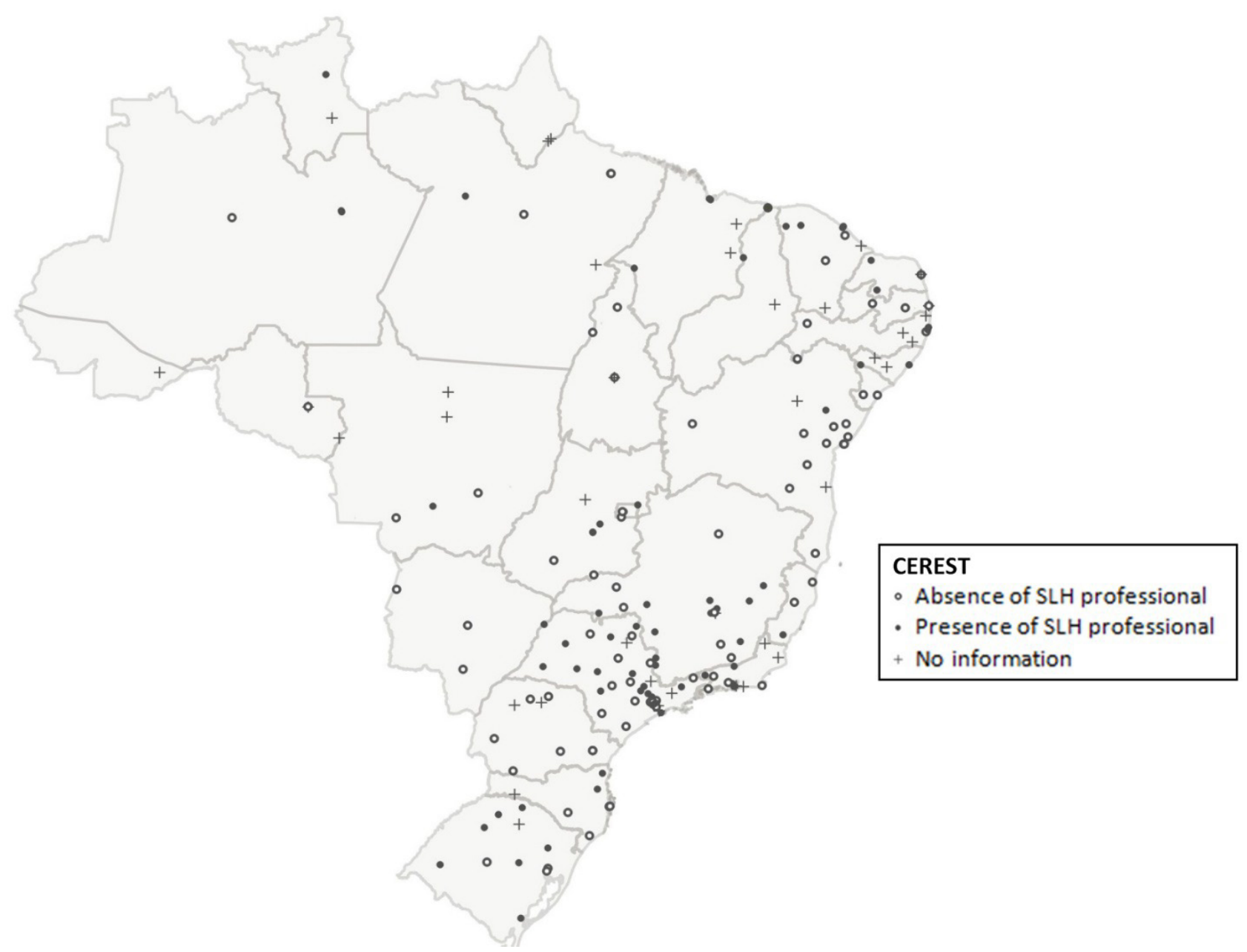

Fiigure 2. Distribution of 210 functioning Worker Health Reference Centres (CEREST) with an SLH professional on the team in Brazil, 2014 
Table 1. Distribution of Worker Health Reference Centres (CEREST) with at least one SLH professional on the team, by geographic region and federal state in Brazil, 2014

\begin{tabular}{|c|c|c|}
\hline \multirow{2}{*}{ Region / Federal State } & \multicolumn{2}{|c|}{ CEREST } \\
\hline & Total N & SLH Professional present N (\%) \\
\hline BRAZIL & 158 & $76(48.1)$ \\
\hline North Region & 12 & 4 \\
\hline Rondônia & 1 & 0 \\
\hline Acrea & - & - \\
\hline Amazonas & 3 & 2 \\
\hline Roraima & 1 & 1 \\
\hline Pará & 5 & 1 \\
\hline Amapáa & - & - \\
\hline Tocantins & 2 & 0 \\
\hline Northeast Region & 41 & 17 (41.5) \\
\hline Maranhão & 3 & 3 \\
\hline Piauí & 2 & 1 \\
\hline Ceará & 6 & 4 \\
\hline Rio Grande do Norte & 3 & 2 \\
\hline Paraíba & 3 & 0 \\
\hline Pernambuco & 6 & 3 \\
\hline Alagoas & 2 & 2 \\
\hline Sergipe & 3 & 1 \\
\hline Bahia & 13 & 1 \\
\hline Southeast Region & 65 & $39(60.0)$ \\
\hline Minas Gerais & 16 & 10 \\
\hline Espírito Santo & 4 & 2 \\
\hline Rio de Janeiro & 10 & 6 \\
\hline São Paulo & 35 & 21 \\
\hline South Region & 25 & $10(40.0)$ \\
\hline Paraná & 8 & 0 \\
\hline Santa Catarina & 6 & 2 \\
\hline Rio Grande do Sul & 11 & 8 \\
\hline Central-west Region & 15 & $6(40.0)$ \\
\hline Mato Grosso do Sul & 3 & 0 \\
\hline Mato Grosso & 3 & 1 \\
\hline Goiás & 6 & 4 \\
\hline Federal District & 3 & 1 \\
\hline
\end{tabular}

${ }^{a}$ Acre and Amapá had no participating CERESTs.

In 2014, of the CERESTs with an SLH professional, the majority recorded a single professional on the team, although some CERESTs had three or more (Table 2). In terms of work contract, the majority of the CERESTs with an SLH professional employed at least one through a statutory contract $(82.9 \%)$. In $15.8 \%$ of the CERESTs, all the SLH professionals were on temporary contracts and there was one CEREST (1.3\%) in which the sole professional was a volunteer. 
Table 2. Distribution of Worker Health Referende Centres (CEREST) according to the number of SLH professionals on the team in Brazil, 2014

\begin{tabular}{ccc}
\hline \multirow{2}{*}{ Number of SLH professionals } & \multicolumn{2}{c}{ CEREST } \\
\cline { 2 - 3 } & $(\mathbf{N}=\mathbf{1 5 8})$ & $\%^{\mathrm{a}}$ \\
\hline 0 & 82 & 51.9 \\
1 & 58 & 36.7 \\
2 & 13 & 8.2 \\
3 & 4 & 2.5 \\
$4 \mathrm{ou}+$ & 1 & 0.6 \\
\hline
\end{tabular}

${ }^{a}$ Due to approximations, numbers do not total $100 \%$.

Of the CERESTs with an SLH professional, health surveillance in general was their most common activity (76.3\%), alongside health surveillance activities aimed at NIHL and/or WRVD (73.7\%) and clinical and/or diagnostic care for voice and/or hearing (65.8\%). The most common SLH activities included all three modalities (Table 3). However, in $7.9 \%$ of the CERESTs, the SLH professional was exclusively dedicated to specialized care.

Table 3. Distribution of Worker Health Reference Centres (CEREST) according to activities undertaken by SLH professionals on the team in Brazil, 2002-2014

\begin{tabular}{ccccc}
\hline \multicolumn{2}{c}{ Activities undertaken by SLH professionals } & \multicolumn{2}{c}{ CEREST with an SLH professional in 2014 } \\
\hline $\begin{array}{c}\text { Clinical and/or } \\
\text { diagnostic care in voice } \\
\text { and/or hearing }\end{array}$ & $\begin{array}{c}\text { Health surveillance } \\
\text { activities (NIHL and/or } \\
\text { WRVD) }\end{array}$ & $\begin{array}{c}\text { Health surveillance } \\
\text { activities in general }\end{array}$ & $\mathbf{N}=\mathbf{7 6}$ & $\%$ \\
\hline$\checkmark$ & & & 6 & 7.9 \\
& $\checkmark$ & $\checkmark$ & 4 & 5.3 \\
& & & 9 & 11.8 \\
& $\checkmark$ & $\checkmark$ & 13 & 10.5 \\
$\checkmark$ & $\checkmark$ & $\checkmark$ & 5 & 17.1 \\
$\checkmark$ & & $\checkmark$ & 31 & 6.6 \\
\end{tabular}

NIHL, Noise-Induced Hearing Loss; WRVD, Work-Related Voice Disorders.

\section{DISCUSSION}

From 2002 to 2014, the presence of SLH professionals in CEREST teams increased. However, in 2014 , the majority of units still did not contain such a professional. When present, it was most common to have a single SLH professional per CEREST. The most common work contract was that of statutory civil servant. The presence of an SLH professional in a CEREST was more common in the Southeast, where six in every 10 units had an SLH professional, in contrast to only three in every 10 in the North. In most of the CERESTs with an SLH professional on their team, the most common activity involved health surveillance activities, although there remained units in which these activities were restricted to specialized clinical care.

\section{Distribution of CERESTs and SLH Services around the country}

The number of CERESTs has grown since 2002, when the first 17 CEREST in the country received accreditation ${ }^{11,12}$. In 2011, there were 210 units across all the federal states $^{13}$. The Ministry of Health's (2015) MultiannualPlan and National Health Plan (2016-2019) has a targetstating that $100 \%$ of all health regions will contain at least one accredited CEREST by 2019. São Paulo was the first state in the country to have a 
regional network of accredited CERESTs ${ }^{14}$. Of the first 17 CERESTs, $35.3 \%$ were located in this state, while the others were in Minas Gerais, Rio Grande do Sul and $\mathrm{Bahia}^{12}$. Despite this evolution, there are factors which impact on theirmode of operation, in other words, the presence ofan accredited health unit does not guarantee that it operates to its potential capacity, thatequitable services are provided for workers, or that services for the population are of high quality or efficient ${ }^{11,15}$. One of these factors may be related to difficulties commonly observed in professional health training, such as conditioning, technical knowledge and a fragmented, generally disease-related,vision characteristics which tend to underestimate the intrinsic subjectivity and singularity of the subject and which do not provide humanized healthcare ${ }^{16}$.

In regions that contain a higher density of workers the Southeast, South and Northeast, there is a greater concentration of CERESTs, while such units are rare in the North and Central-west regions ${ }^{11}$. The North region has an even lower proportion of CERESTs with an SLH professional, which makes it more difficult for the unitsand their teams to operate effectively, given that they face the challenge of developing strategies thatachieve coverage for their entire territory. Clearly, greater reach across the network is desirable in order to disseminate WH activities. In contrast, the Southeast region has a greater proportion of CERESTs with an SLH professional. In this region, onewithsignificantindustry, one may observe the development of systematic WH programmes and activities ${ }^{11}$, significant scientific production in the area ${ }^{17}$ and a history of early CERESTs accreditation ${ }^{14}$.

\section{The SLH professional within CEREST teams}

Although Decree 2437/2005 establishes the minimum composition of state and regional CERESTs, in $2010,60.5 \%$ of these did not contain a minimum team ${ }^{11}$. This contributed, in part, to an understanding of the still incipient inclusion of the SLH professional, given that they are not a compulsory component of the minimum team. Other professionals may also have less representation in CERESTs. Difficulties in constituting the team may occur because of a lack of human resources working in public health services, difficulties in hiring at municipal level ${ }^{11}$, precarious employment contracts and the high turnover of technical professionals ${ }^{18,19}$, among other factors. According to the Renast Report about the establishment of the National Worker Health Policy (2016), in 2014/2015 there was an increase in all the CEREST professional categories, with a greater concentration of nurses and doctors, whose presence in the minimum team is compulsory.

Clearly, decisions about team compositionmust be influenced by the profile of production and morbidity in the area covered by each CEREST. In this sense, the inclusion of an SLH professional is desirable, given the noise present in most production processes ${ }^{5}$ and the fact that WRVDs predominantly affect teachers ${ }^{20}$, an occupation with significant representation around the country. On the contrary, however, this studied revealed large territorial areas in Brazil where there was no SLH professional in the CERESTs in the North, Central-West and Northeast regions, in the north of Minas Gerais and in Paraná.

Other factors may also have contributed to the low presence of SLH professionals in the CEREST, including the relatively recent incorporation of this profession into public health services ${ }^{21}$. The inclusion and valuation of Collective Health content within the graduation curricula for SLH Sciences has only recently occurred and itsprevious absence accentuated clinical training aimed at healthcare, in detriment to collective activities consistent with health policies ${ }^{22}$. Furthermore, there is a gap between theory and practice during training courses, incurricular components and Collective Health internships ${ }^{23}$. The National Curricular Guidelines for the SLH Course are aimed at training generalist and humanist professionals. However, this does not guarantee that hegemonic concepts and practices, reinforced in higher education training institutions, are overcome. It is necessary to promote training based on the population's health needs, towards a healthcare model which prioritizes comprehensive care and the humanization of healthcare ${ }^{16}$.

According to Decree 154 of 24 January 2008, althoughthe national health policies of recent years have promoted SLH services within SUS, such professionals are only just beginning to be included and the number of vacancies for public posts is incompatible with demand. In 2009, in Minas Gerais, for every 17,000 state residents, there was only one SLH professional in SUS ${ }^{24}$. In 2014, in the capitals of the Northeast, the average SLH provision was only 1.5 professionals for every 100,000 inhabitants, when looking at vacancies under direct municipal administration ${ }^{25}$. Inequalitieswere also identified in SLH procedures in SUS health services, with an estimated figure lower than the national average for the North and Northeast 
regions ${ }^{26}$. There remains evidence of an absence of coverage for more than half the Brazilian population ${ }^{27}$.

Our study also confirmed a predominance of statutory contracts for SLH professionals in those CERESTs that included them. This result is consistent with a statement made by Dias et al. $(2010)^{28}$ that $70 \%$ of the workers who constitute the CEREST teams have statutory contracts. Although the majority of SLH professionalspossess such contracts, the turnover of professionals in these teams may prevent continuity in the provision of surveillance activities. According to a study by Santos and Lacaz (2012) ${ }^{29}$, the turnover of health professionals is one of the problems CERESTs face, since it interferes with team integration and worker healthcare.

\section{The work of the SLH professional at CERESTS}

In most of the study CERESTs which had a SLH professional on their team, the professional's work involved health surveillance activities and clinical and/ or diagnostic practices related to voice and/or hearing. However, there were units in which the SLH professional only worked in specialized clinical care, with no involvement in health surveillance activities, even those related to the professional's field. The case study of the CEREST in Campinas demonstrated that there was a greater emphasis on care in the 2001 activities than in 2012, but, despite successive attempts aimed at strengthening surveillance over this periodin the search for comprehensive WH care, clinical care still received the most investment. Structural limitations, related to training and to institutional and political problems, were identified as barriers to the full attainment of WH policy ${ }^{30}$. In 2011 , only $12 \%$ of the CEREST carried out WH surveillance activities, which rose to $66.7 \%$ in 2013 , an important advance,given the Ministry of Health targetto achieve $100 \%$ in $2015^{13,31}$. It is worth noting that, in 2014, in76.3\% of the CEREST in this study which included an SLH professional, the professional carried out health surveillance activities, very close to the figure for 2014 of $80 \%$, established by the Strategic Agenda Indicators of the Ministry of Health's Department of Health Surveillance (2012-2015).

Consistent with this, Resolution 428 of the Federal Council of SLH Sciences (2013) which establishes the attributions of competence of SLH professionals who operate in $\mathrm{WH}$, recognizes the perspectives of health surveillance, the prevention of injuries such as NIHL and WRVD, health promotion, as well as specialized clinical care. It is worth noting that one of the CEREST's attributions is to provide support to the SUS network regarding the notification of WH injuries to the Notifiable Diseases Information System (Sistema de Informação de Agravos de Notificação -SINAN), and that NIHL is included in the list of injuries formandatory notification.

In 2017, the Ministry of Health recognized WRVD and referred a protocol for publication, representing an important advance for $\mathrm{WH}$ and for formally extending the work of the SLH professional within the CEREST teams. This step must be strengthened through actual publication and the inclusion of this injury in the Social Security list ${ }^{20,32}$.

There are few studies about SLH Sciences in WH, which may, in part, reflect the recent, gradual and still insufficient inclusion of the professional within the sphere of Public Health at SUS ${ }^{26}$, specifically in relation to health surveillance activities. Under these circumstances, it is essential to promote discussion about the foundations of health surveillance, which must support priority SLH activities in CEREST. Naturally, relationships between working conditions and the healthillness process require SLH activities in favour of worker health at all levels of care.

\section{Limits and advantages}

A little over twenty percent (20.6\%) of the CEREST in our study did not respond, a figure consistent with expectations, given long-distance data collection. Nevertheless, these results should be treated with caution, since they may not reflect what occurs in all CERESTs. During data collection, for example, some CERESTs justified their non-participation because they did not have an SLH professional on their team, although they were aware that this was not a prerequisite. It is therefore likely that the absence of an SLH professional at the CEREST is more common among non-respondents than those that participated. Data related to previous years may be imprecise due to memory bias, which may have occurred in relation to the presence of the SLH professional during the 2000s, or even indicate that the SLH professional was registered in the year prior to the unit's accreditation as a CEREST. In contrast, the study reveals information about a scenario that remains little-known, providing evidence about SLH Sciences within the country's CEREST. 


\section{CONCLUSION}

Since the beginning of the establishment of CERESTs, there has been a growing presence of SLH professionals on their teams, although more than half of these units did not contain such a professional. It is possible that the inclusion of SLH professionals on the teams will be shaped as a strategy to drive health surveillance activities, particularly in the fields of $\mathrm{NIHL}$ and WRVD. The study describes and investigates the initial inclusion of SLH professionals in CERESTs, contributes to evidence that indicates regional inequalities, and reveals that there remain services in which the work of the SLH professional is restricted to clinical care.A broader understanding of the work of these professionals within CEREST is required, one consistent with public policies for health surveillance. In this sense, positive changes may lead to the inclusion of worker health surveillance in the professional training curricula and in continued education, as well as in enriching partnerships between teaching and services.

\section{REFERENCES}

1. Almeida SIC, Albernaz PLM, Zaia PA, Xavier OG, Karazawa EHI. História natural da perda auditiva ocupacional provocada por ruído. Rev Assoc Med Bras. 2000;46(2):143-58.

2. Fernandes M, Morata TC. Estudo dos efeitos auditivos e extra-auditivos da exposição ocupacional a ruído e vibração. Rev. Bras. Otorrinolaringol. 2002;68(5):705-13.

3. Guerra MR, Lourenço PMC, Bustamante-Teixeira MT, Alves MJM. Prevalence of noise-induced hearing loss in metallurgical company. Rev Saúde Pública. 2005;39(2):238-44.

4. Araújo SA. Perda auditiva induzida pelo ruído em trabalhadores de metalúrgica. Rev. Bras. Otorrinolaringol. 2002;68(1):47-52.

5. Concha-Barrientos $M$, Campbell-Lendrum $D$, Steenland K. Occupational noise: assessing the burden of disease from work-related hearing impairment at national and local levels. In: World Health Organization. Environmental burden of disease series 9. Geneva: OMS; 2004. p.8-12.

6. Meira TC, Ferrite S, Cavalcante F, Corrêa MJM. Exposição ao ruído ocupacional: reflexões a partir do campo da Saúde do Trabalhador. InterfacEHS. Rev Saúde Meio Amb Sustentab. 2012;7(3):26-45.
7. Ferreira LP, Martz MLW. Distúrbios da voz relacionado ao trabalho: a experiência dos Cerest. Boletim Epidemiológico Paulista. 2010;7(75):13-9.

8. D'Oliveira CMC, Torres FF. Notificação do distúrbio de voz relacionado ao trabalho: relato de experiência pioneira no Brasil. Distúrb. Comun. 2011;23(1):97-9.

9. Ferreira LP, Bernardi APA. Distúrbios da voz relacionado ao trabalho: resgate histórico. Distúrb. Comun. 2011;23(2):233-6.

10. Dias EC, Hoefel MG. O desafio de implementar as ações de Saúde do Trabalhador no SUS: a estratégia da RENAST. Ciên Saúde Colet. 2005;10(4):817-28.

11. Brasil. Ministério da Saúde. Fundação Oswaldo Cruz. Universidade Federal da Bahia. 2은 Inventário de Saúde do Trabalhador, 2010-2011: acompanhamento da Rede Nacional de Atenção Integral em Saúde do Trabalhador, 2010-2011. Fiocruz, UFBA, 2013. Brasília; 2013 [Internet] [accessed on 21 Aug. 2017]. Available at: http:// renastonline.ensp.fiocruz.br/sites/default/files/ arquivos/recursos/Inventario\%20RENAST\%20 2010-2011.pdf

12. Brasil. Ministério da Saúde. Portaria GM № 994, de 19 de dezembro 2002. Dispõe sobre a habilitação dos Centros de Referência em Saúde do Trabalhador. Brasília; 2002. [Internet] [accessed on 19 May 2017]. Available at: http://www.jusbrasil. com.br/diarios/814441/pg-301-secao-1-diariooficial-da-uniao-dou-de-20-12-2002

13. Brasil. Ministério da Saúde. Portaria GM № 2.978, de 15 de dezembro de 2011. Amplia para 210 (duzentos e dez) a quantidade de Centros de Referência em Saúde do Trabalhador (CEREST) passíveis de implantação no território nacional. Brasília; 2011 [Internet] [accessed on 21 Aug. 2017]. Available at: http://www.jusbrasil.com.br/ diarios/33259188/dou-secao-1-16-12-2011-pg-89

14. Secretaria de Saúde do estado de São Paulo. Centro de Referência em Saúde do Trabalhador de São Paulo. Processo de implantação da saúde do trabalhador no SUS/SP. Rev Saúde Pública. 2004;38(3):471-4.

15. Cardoso MCB, Araújo TM. Workers' Health Reference Centers performance in mental health: a survey in Brazil. Rev Bras Saúde Ocup. 2016;41(e7):1-13.

16. Miranda AO, Arce VAR. Humanization in health professional education: the experience of a speech, 
language and hearing sciences student. Distúrb. Comun. 2015;27(3):600-7.

17. Bezerra MLS, Neves EB. Perfil da produção científica em saúde do trabalhador. Saúde Soc. 2010;19(2):384-94.

18. Santos APL. Tecendo redes, superando desafios: estudos dos processos de trabalho de casos exitosos em Saúde do Trabalhador no Sistema Único de Saúde do Estado de São Paulo [tese]. São Paulo (SP): Universidade Federal de São Paulo, Departamento de Medicina Preventiva; 2010.

19. Gomez CM, Vasconcellos LCF, Machado JMH. Saúde do trabalhador: aspectos históricos, avanços e desafios no Sistema Único de Saúde. Ciênc Saúde Colet. 2018;23(6):1963-70.

20. Masson MLV, Ferrite S, Pereira LMA, Ferreira LP, Araújo TM. Em Busca do reconhecimento do distúrbio de voz como doença relacionada ao trabalho: movimento histórico-político. Ciênc. Saúde Colet. 2017 [Internet] [accessed on 16 Jan. 2018]. Available at: http://www. cienciaesaudecoletiva.com.br/artigos/em-buscado-reconhecimento-do-disturbio-de-voz-comodoenca-relacionada-ao-trabalho-movimen to-historicopolitico/16357

21. Befi D. Fonoaudiologia na atenção primária à saúde. São Paulo: Lovise; 1997.

22. Lemos M, Bazzo LMF. Formação do fonoaudiólogo no município de Salvador e consolidação do SUS. Ciênc Saúde Colet. 2010;15(5):2563-8.

23. Moura $D$, Arce VAR. Atenção primária à saúde: concepções e práticas de docentes fonoaudiólogos. Distúrb. Comum. 2016;28(1):130-41.

24. Santos JN, Maciel FJ, Martins VO, Rodrigues ALV, Gonzaga AF, Silva LF. Inserção dos fonoaudiólogos no SUS/MG e sua distribuição no território do estado de Minas Gerais. Rev. CEFAC. 2012;14(2):196-205.

25. Santos JAP, Arce VAR, Magno LD, Ferrite S. Provision of Speech, Language and Hearing services in the public municipal healthcare network in the state capitals of Northeast Brazil. Audiol Commun Res. 2017;22:(e1665):1-8.

26. Miranda GMD, Mendes ACG, Silva ALA, Rodrigues M. Phonoaudiological care in the SUS: expanding access and the challenge of overcoming inequalities. Rev. CEFAC. 2015;17(1):71-9.

27. Viégas LHT, Meira TC, Santos BS, Mise YF, Arce VAR, Ferrite $S$. Speech, language and hearing services in primary health care in Brazil: an analysis of provision and an estimate of shortage, 2005-2015. Rev. CEFAC. 2018;20(3):353-62.

28. Dias EC, Chiavegatto CV, Silva TL, Reis JC, Silva JM. Construção da RENAST em Minas Gerais: a contribuição dos Centros de Referência em Saúde do Trabalhador (CEREST), 2002-2007. Rev Med Minas Gerais. 2010;20(2):66-74.

29. Santos APL, Lacaz FAC. Apoio matricial em saúde do trabalhador: tecendo redes na atenção básica do SUS, o caso de Amparo/SP. Ciênc Saúde Colet. 2012;17(5):1143-50.

30. Medeiros MAT, Salerno VL, Silvestre MP, Magalhães LV. Política de saúde do trabalhador: revisitando o caso do Centro de Referência em Saúde do Trabalhador de Campinas. Rev Bras Saúde Ocup. 2013;38(127):81-91.

31. Brasil. Ministério da Saúde. Secretaria-Executiva. Subsecretaria de Planejamento e Orçamento. Plano Nacional de Saúde - PNS 2012-2015. Brasília; 2011. (Série B. Textos básicos de saúde). Brasília; 2011c [Internet] [accessed on 19 Aug. 2017]. Available at: http://conselho.saude.gov.br/biblioteca/Relatorios/ plano_nacional_sau de_2012_2015.pdf

32. Faculdade de Ciências Médicas. DVRT segue para publicação, anuncia representante do MS em avento internacional da voz. 2017 [Internet] [accessed on 17 Dec. 2017]. Available at: https:// www.fcm.unicamp.br/fcm/relacoes-publicas/ saladeim prensa/dvrt-segue-para-publicacaoanuncia-representante-do-ms-em-evento-interna cional-da-voz 


\section{APPENDIX. Data collection questionnaire, applied via electronic form}

Name of CEREST:

City: State:

Date of completion:

Respondent's name:

Role at CEREST:

1. How many SLH professionals currently work for the CEREST team? Consider all types of work contract.
( ) 0 (none)
( ) 1
( ) 2
( ) 3
( ) 4 or more

2. How many SLH professionals have you had on the team in the past? (that are no longer part of the team)
( ) 0 (none)
( ) 1
( ) 2
( ) 3
( ) 4 or more

3. Please provide the year that these SLH professional(s) joined this CEREST. If you are unsure, please select the nearest possible number. Start with the current team, followed by those who are no longer part of the team (where relevant).
SLH prof. 1
SLH prof. 2
SLH prof. 3
From (year of entry) From:
SLH prof. 5
(year of entry) From:
SLH prof. 6
(year of entry)
SLH prof. 4 (year of entry)

From: - (year of entry) From: $\overline{\text { Thear of entry) From: }}$ (y) never been an SLH professional on our CEREST team.

From:
There has never been an SLH professional on our CEREST team.

4. Please advise whether the SLH professional is still working on the team, or the year they left. If you are unsure, please select the nearest possible number. Please maintain the order from your previous answer.

SLH prof. 1

From:

SLH prof. 3

From: 2014, 2014, 2013, 2012,...)

\section{SLH prof. 5}

From: (Worked in 2014, 2014, 2013, 2012,...
SLH prof. 2

From: SLH prof. 4

From: SLH prof. 6

From: (Worked in 2014, 2014, 2013, 2012,...) (Worked in 2014, 2014, 2013, 2012,...) (Worked in 2014, 2014, 2013, 2012,...)

5. Please provide the type of working contract for each SLH professional. Please maintain the order from your previous answer. SLH prof. 1
( ) statutory contract
( ) temporary contract/outsourced
( ) volunteer
( ) other:

SLH prof. 2

( ) statutory contract ( ) temporary contract/outsourced ( ) volunteer ( ) other:

SLH prof. 3
( ) statutory contract
( ) temporary contract/outsourced
( ) volunteer
( ) other:

SLH prof. 4

\section{SLH prof. 5}
( ) statutory contract
( ) temporary contract/outsourced
( ) volunteer
( ) other:

( ) statutor

SLH prof. 6
( ) statutory contract ( ) temporary contract/outsourced

( ) volunteer

( ) other:

6. The SLH professional's work on your team involves/d:

( ) only "a" ( ) only "b" ( ) only "c" ( ) "a" and "b" ( ) "b" and "c" ( ) "a" and "c" ( ) all of these activities
a. Clinical and/or diagnostic care in voice and/or hearing
b. Health surveillance activities (NIHL and/or WRVD)
c. Health surveillance activities in general

7. To finish, please rate your response to the following statement: "The work of the SLH professional on this CEREST team has positively contributed to activities related to NIHL notifications to SINAN (the SUS Notifiable Diseases Information System)".

( ) Totally agree ( ) Somewhat agree ( ) Neither agree nor disagree

( ) Somewhat disagree ( ) Totally disagree

8. To finish, please rate your response to the following statement: "The inclusion of an SLH professional on this CEREST team would positively contribute to worker health surveillance activities, including NIHL notifications to SINAN (the SUS Notifiable Diseases Information System)".

( ) Totally agree ( ) Somewhat agree ( ) Neither agree nor disagree （） Somewhat disagree ( ) Totally disagree 